\title{
Alignment of Capital Structure to the Requirements of the General Strategy
}

\author{
Vukašin Kuč \\ Faculty of Economics University of Belgrade
}

\begin{abstract}
This paper deals with cardinal concepts in the field of economic theory and business management: capital structure and strategy. Although there are a number of papers dealing with these concepts, the relationship between the capital structure and strategies is still an underexplored area. Despite the fact that there is a two-way influence between them, this paper attempts to explain why a particular strategy choice requires adjusting the capital structure. Relevant theories, concepts, and numerous empirical studies were used for this purpose. The mismatch between the elements of the business and financial strategy can lead not only to a decrease in the value of the company but also to its liquidation. The focus of this paper is on general (grand or corporate) strategies related to the enterprise level. There are three basic types of general strategies: 1) growth strategies; 2) stabilization strategies; and 3) retrenchment strategies. Consequently, this paper is structured to show how the capital structure adapts to the specific requirements of these three types of general strategies. Understanding the relationship between strategy and capital structure is essential for achieving and maintaining competitiveness, especially in a rapidly changing context.
\end{abstract}

Keywords: capital structure, general strategy, growth strategy, stabilization strategy, retrenchment strategy

\section{Introduction}

The strategy is a key planning decision that should lead to the achievement of the goals of the enterprise. There are three types of strategies according to the level to which they relate: 1) general strategies; 2) business strategies; and 3) functional strategies. This paper deals with the general strategies. 


\section{MANAGEMENT, BUSINESS \& FINANCE}

A general strategy is a company-level strategy. It is often referred to as corporate strategy or grand strategy. The focus of this strategy is to balance the resources and opportunities to maximize enterprise value. There are three basic types of general strategy: 1) growth strategies; 2) stabilization strategies; and 3) retrenchment strategies.

The corporate strategy could be understood as a manifestation of managerial values, goals, and preferences of top managers. The choice of a particular general strategy should lead to a specific mix of debt and equity. The corporate strategy affects the capital structure through its impact on the company's performance and risk level (Jordan et al., 1998). Therefore, the current capital structure is a consequence of the implementation of the past/current business strategy (Kaličanin \& Todorović, 2014; Kuč, 2015). On the other side, the current capital structure influences the choice of future strategy by limiting the flexibility in managerial decisionmaking. An enterprise may miss an opportunity for extraordinary growth if the current capital structure does not support or impede the selection and implementation of specific strategic projects (Kuč \& Kaličanin, 2018).

Modigliani \& Miller's proof of the capital structure irrelevance when it comes to the enterprise value (1958) could also be understood as the irrelevance of the capital structure for the corporate strategy. However, modern theories of capital structure have rejected the previous claim. If the financing structure affects value (a consolidated measure of the quality of the strategy), then it must have an impact on the strategy that represents the chosen path of value creation. The strategic importance of the capital structure was indicated by Barton and Gordon (1987, 1988), Bromiley (1990), Chatterjee and Wernerfelt (1991), Kochhar (1996), Kochhar and Hitt (1998) and others. The concept of value maximization has contributed to a better understanding of the interplay between strategy and financial structure as well as the concept of product (or business) cycle.

\section{Growth strategies and capital structure}

There are a number of strategies and methods that can be used to increase the size of the company. Depending on whether the sources of growth are within or outside the existing business area, growth strategies are divided into two groups: intensive growth strategies and diversification strategies (Ansoff, 1957).

The intensive growth strategies look for growth potential within the existing business area. There are three alternatives: market penetration, market development, and product development. Market penetration strategy focuses on increasing sales of an existing product in an existing market. The market development strategy focuses on increasing the sales of an existing product in new markets. Growth based on the introduction of new modified, upgraded products in the existing market is achieved through a product development strategy (Đuričin et al., 2018, pp. 520-521). 
Unlike intensive growth strategies, diversification strategies imply that growth opportunities are sought outside the comfort zone (existing business area). It is about growing sales by introducing new products to new markets. Depending on the extent to which new products/services are related to the existing core of competence (knowledge, skills, technology), a distinction is made between related and unrelated diversification.

Evolution of the enterprise growth, as a rule, implies that enterprise first exploits the sources of growth in the existing business area by applying alternative intensive growth strategies and combining them. Diversification is a response to growth constraints in the current framework. Growth strategies can be implemented through internal and external growth methods. Internal (or organic) growth refers to the growth of a company through the realization of investment projects (for example, by expanding existing and/or building new capacities), while external growth is achieved through a merger and/or acquisition with other companies. Combining organic and external growth is achieved through strategic alliances.

The implementation of any growth strategy entails specific risks. Previous growth strategies are different in terms of both the nature of the risk (commercial, technological, etc.) and the level of risk. The risk of a particular growth strategy is directly determined by its distance from the core competence of the company. Starting from that, market penetration strategy is the least risky strategy, followed by market development strategy, product development strategy and diversification strategy as the riskiest alternative.

It is interesting that a completely different picture is obtained if we change the perspective of observation and observe the risk at the level of the business portfolio. Although entering the business area with the most unknowns carries the highest risk, the diversification strategy reduces (diversifies) the overall investment risk of the corporation. Gravity to an existing product and market, on the other hand, increases a company's exposure to the adverse effects of systematic risk factors. The chosen growth method also influences the overall level of risk of the growth strategy.

The aim of the general strategy is not to minimize (commercial, technological, financial, etc.) the risk, but to maximize the value of the enterprise. In this sense, a lower risk strategy is not better than a higher risk strategy. The quality of a strategy is measured by the level of created value. Whether a particular strategy will lead to value creation depends on its compatibility with the strategic context and the ability of managers to implement it appropriately.

After the huge wave of unrelated (conglomerate) diversification during 1960-1980, the opposite trend emerged. The reason for this was the frequent occurrence of the value destruction by conglomerates. The affirmation and development of value-based management revealed the negative side of the diversification and growth imperative. Development and implementation of the so-called economic (value-based) indicators in practice have shown that every growth is not profitable and desirable growth. The use of available cash flow just to build the managerial 


\section{MANAGEMENT, BUSINESS \& FINANCE}

empire could lead to the well-known managerial overinvestment problem (Brito \& John, 2002). In the absence of attractive investment options that would lead to above-average returns, distributing the available cash flow to owners is a better strategy. Enterprise value could be also enhanced by implementing restructuring and retrenchment strategies.

The fundamental managerial concept of the product (business) life cycle provides a useful framework for understanding the relationship between business and financial strategy (Johnson et al, 2011, pp. 384-385). The choice of capital structure as a driver of financial risk is determined by the level of business risk in a given life cycle stage. Business and financial risk must be reversed to keep the overall risk at an acceptable level. Unlike most business risk factors that are beyond the reach of the business, capital structure is a controllable variable. Of course, capital structure is not immune to the influence of external factors (primarily financial markets). Managers of overvalued companies usually issue equity, while managers of undervalued use available cash (Myers \& Majluf, 1984).

In the first (development/launch) phase, when the level of business risk is very high, the financial risk must be kept at a minimum. Venture capital is an appropriate source of financing at the beginning of a business life cycle. The capital investments immanent for the first stage of growth phase are financed by raising additional equity capital. Moving on to the next stages of the life cycle, the level of business risk gradually decreases leaving the room for increasing financial leverage (financial risk). In the maturity stage, when there are a high and stable positive cash flow and low investment requirements, high creditworthiness enables the necessary financial resources to be obtained from cheaper borrowed sources. In the last stage of the life cycle, debt is a major external source of financing. Investors are not interested in investing due to a significant decline in sales and returns, while available assets (collateral) provide security to creditors. With the passage of a life cycle, in addition to changes in funding sources, dividend policy does not remain unchanged. For example, while there is no a dividend payment in the introduction phase, in the last phase dividend payment should be at the maximum level (Kuč \& Kaličanin, 2018). 
Figure 1: Financial strategy over the life cycle of a product (business)

\begin{tabular}{|c|c|}
\hline $\begin{array}{l}\text { Growth } \\
\text { - Business risk: high } \\
\text { - Financial risk should be: Low } \\
\text { - Financial resources: equity (increase in } \\
\text { number of owners) } \\
\text { - Dividends: nominal }\end{array}$ & $\begin{array}{l}\text { Development/Launch } \\
\text { - } \text { Business risk: very high } \\
\text { - } \text { Financial risk should be: very low } \\
\text { - } \text { Financial resources: equity (venture capital) } \\
\text { - } \text { Dividends: no dividends }\end{array}$ \\
\hline $\begin{array}{l}\text { Maturity } \\
\text { - Business risk: moderate } \\
\text { - Financial risk should be: moderate } \\
\text { - Financial resources: debt and equity } \\
\text { (retained earnings) } \\
\text { - Dividends: high }\end{array}$ & $\begin{array}{l}\text { Decline } \\
\text { - } \text { Business risk: low } \\
\text { - } \text { Financial risk should be: high } \\
\text { - } \text { Financial resources: debt } \\
\text { - } \text { Dividends: high }\end{array}$ \\
\hline
\end{tabular}

Source: adopted from Johnson, Whittingtonm \& Scholes, 2011, p. 384

The life cycle concept describes the interdependence of business and financial strategy at the level of one product (business). Considering that large enterprises in their portfolio have a larger number of businesses located at different stages of the life cycle, in different types of branches and with a different competitive position in the branch, it is clear that the financial strategy at the enterprise level arises as a result of harmonization and consolidation business-level financial strategies in a way that ensures complementarity with the overall company strategy (Lubatkin \& Chatterjee, 1994). The investment and financial strategy of the company must be mutually compatible. Failure to do so may result in bankruptcy.

When it comes to growth strategies and their relationship with the capital structure, the vast majority of theoretical and empirical research is focused on diversification. Rumelt (1974) found that one-business enterprises and those that implement a related diversification strategy are more risk aversive (prudent use of debt) than companies that apply unrelated diversification. The previous claims were empirically tested by Barton and Gordon (1988). Relying on Rumelt's methodology on a sample of 279 companies, these authors came to the same conclusion. The average level of debt of non-diversified enterprises and those implementing related diversification is significantly lower compared to enterprises applying unrelated diversification. Taylor and Lowe (1995) confirmed that firms that implement an unrelated diversification strategy have the largest share of debt in the financial structure. 


\section{MANAGEMENT, BUSINESS \& FINANCE}

30 October - 1November , 2019

Diversification combined with low financial leverage encourages managerial overinvestment ( $\mathrm{Li} \& \mathrm{Li}, 1996$ ). Kochhar and Hitt (1998) found that equity is the preferred source of financing for related diversification, while debt is the preferred source of unrelated diversification. Investors can diversify their portfolio directly by buying shares of other companies. Also, debt financing brings with it the proper discipline in managing the cash flow of a business. Debt covenants could discourage a company from engaging in mergers, additional borrowing, paying dividends or other actions, which leads to an increase in the influence of creditors on a company's decision making (Lemmon \& Zender, 2019). Debt as a control instrument is less demanded in countries with stronger investor protection, while it remains necessary in companies with more diverse boards that are not able to limit managerial discretion and entrenchment (Villarón-Peramato et al., 2018).

The decision on whether to go for related or unrelated diversification is significantly influenced by the characteristics of the company's assets. If the assets are of a specific and narrow purpose then it is more likely that the company will opt for related diversification so that it can be applied to a new business. This is especially true if the company owns valuable intangible assets for specialized purposes (Chatterjee \& Wernerfelt, 1991). The essence of related diversification lies precisely in the division of activities and the transfer of knowledge and intangible assets (economy of breadth) in order to exploit and develop the existing competitive advantage. The focus of related diversification is to create value based on business synergy. The potential for business synergy in the case of unrelated diversification is marginal, which is why the focus of this strategy is to achieve financial synergy. The related diversification strategy offers greater potential for value creation over unrelated diversification because it allows value to increase at the business and enterprise levels, whereas in the case of unrelated diversification it only occurs at the enterprise level (Kochhar \& Hitt, 1998).

In their longitudinal study, La Rocca et al. (2009) confirmed that related and unrelated diversification had the opposite effect on debt. Related diversification has a negative impact on debt level, while unrelated diversification has a positive effect. This group of authors made another important difference. Undertakings using an unrelated diversification strategy maintain financial leverage close to the target level, which is consistent with the static trade-off theory, while this is not the case with related diversification (focus on business synergy).

The key argument invoked by the bulk of research in explaining the relationship between growth strategies and capital structures is that diversification leads to a reduction in business risk due to the weaker correlation of cash flows from different businesses (so-called „,coinsurance effect"). Due to lower business risk at the enterprise (portfolio) level, or less volatility of cash flows, unrelated diversification provides greater opportunities (capacity) for borrowing (Moyer et al., 2012, p. 472). In doing so, it should be remembered that increasing 


\section{MANAGEMENT, BUSINESS \& FINANCE}

the degree of unrelated diversification has a negative impact on the profitability of the company (Rumelt, 1982).

Fundamental theories of corporate governance such as agency theory and transaction cost theory represent the basis of empirical research. From the perspective of agency theory (Jensen, 1986), funding sources are viewed as instruments of corporate governance to minimize the negative effects caused by a conflict of interest in the principal-agent relationship. Thus, for example, the high share of debt to fund unrelated diversification is explained by the increased need for owners to ensure disciplined cash flow management by managers.

According to the transaction cost theory, the capital structure is viewed through the prism of the potential transaction costs of the alternative sources of financing (Williamson, 1988). The transaction costs of debt and equity are primarily determined by the characteristics of the asset, namely its asset specificity. Debt is the preferred source of asset financing that can be easily sold and reallocated without loss of value (nonspecific assets) making it suitable as debt collateral. Highly specific assets, due to less marketability and greater uncertainty about future value, increase the risk of potential creditors as well as the cost of debt. In such circumstances, equity is an adequate source of financing. (Simerly \& Li, 2000).

Value-based management is a good framework for understanding the relationship between general strategy and capital structure. Value-based management "aligns strategies, policies, performance, measures, rewards, organization, processes, people, and systems to deliver increased shareholder value" (Black et al., 1998, p. 292). The ultimate goal of management is to maximize the value of the company, that is, to maximize the value of strategy. If the value is measured using a discounted cash flow model, the role and impact of capital structure could be easily recognized. For a particular level of cash flows, the value increases as the cost of capital (discount rate) decreases. This is the reason why value maximization is often equated with the cost of capital minimization. However, this is not correct because the capital structure not only affects the cost of capital but also the volume of future cash flows. Consequently, an increase in value due to a decrease in the cost of capital may be offset by a loss of value due to missed cash flows caused by a given financing structure (financial inflexibility) (Koller, 2015; Kuč \& Kaličanin, 2018).

The previous issue can best be explained by the hypothetical example of two companies (Pettit, 2007, p. 155). Company $\mathrm{X}$ is a fast-growing company, while Company $\mathrm{Y}$ is in its maturity stage. Both companies achieve maximum value but with different capital structures, that is, different cost of capital (see Figure...). Company $\mathrm{X}$ achieves maximum value at low financial leverage (credit rating $\mathrm{A}$ ) at which the cost of capital is not at a minimum, while company $\mathrm{Y}$ achieves maximum value at a minimum cost of capital (credit rating B). 


\section{MANAGEMENT, BUSINESS \& FINANCE}

Figure 2: Minimization of cost of capital versus Maximization of company value

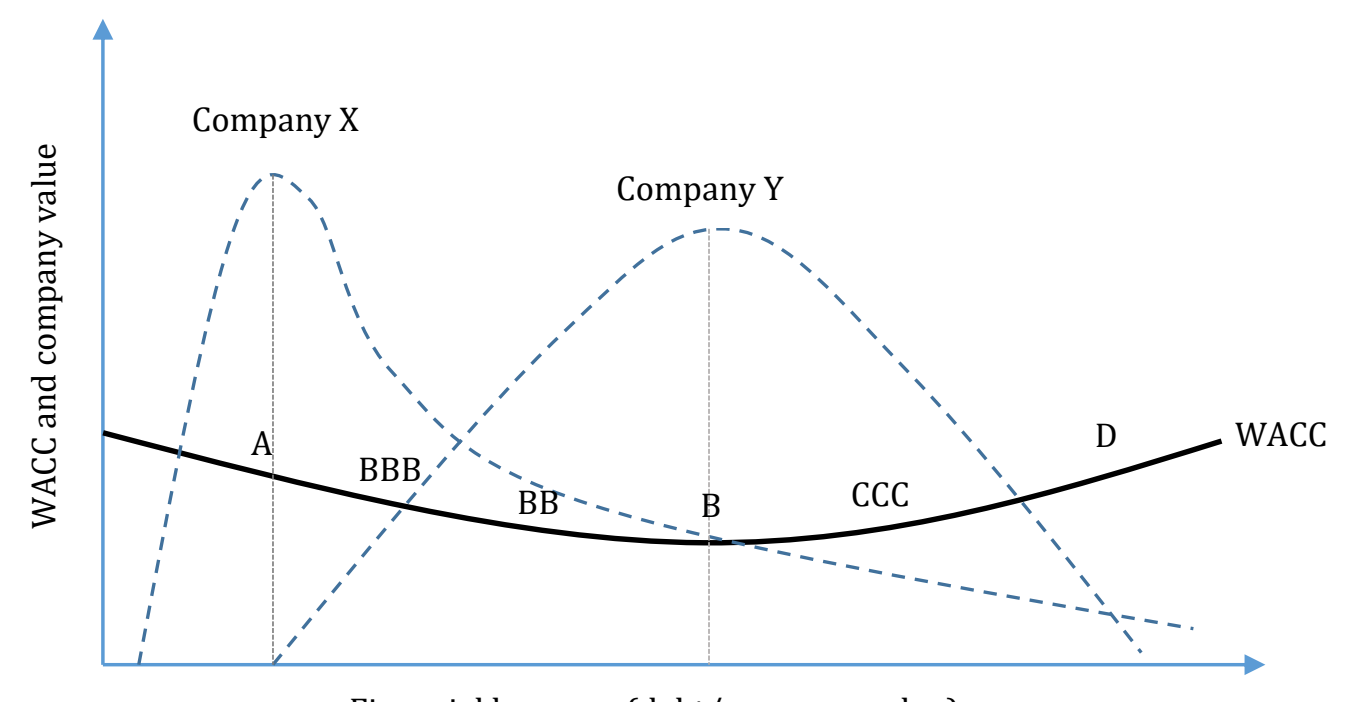

Financial leverage (debt/company value)

Source: Pettit, 2007, p. 155

As most of Company X's value is based on projected growth in future cash flows, maintaining financial strength and flexibility is of paramount importance. Minimizing the cost of capital in the case of company $\mathrm{X}$ would not be an adequate financial strategy because it does not lead to value maximization. The financing structure should support achieving the expected growth. Unlike a fast-growing company, a mature company Y with stable cash flows and a lack of growth opportunities does not require a high level of financial flexibility. The value of this company is based on the projection of the achieved level of cash flows, thereby minimizing the cost of capital (by increasing financial leverage) at a given level of cash flows leads to the value maximization of company $Y$. Therefore, the optimal capital structure is not a combination of debt and equity that minimizes the cost of capital but maximizes the value of the company (Kuč \& Kaličanin, 2018).

\section{Stabilization strategies and capital structure}

Although growth maximization is one of the most commonly pursued goals in practice, it is well known that any growth is not healthy and profitable growth. Implementation of a growth strategy is sometimes not possible, and sometimes it is not the wisest choice since it can lead to value destruction. 
Stabilization strategies include incremental growth at the enterprise level, slowing down or temporarily delaying growth. The company continues to operate within the existing framework without significant changes, which is why these strategies are called status quo strategies. The essence of the stabilization strategy is the exploitation and capitalization of the existing business portfolio and the realized position of the company (Hoffmann, 2007). Stabilization can be accomplished by applying different strategic options such as no-change strategy, pause strategy, harvest strategy.

A stabilization strategy is usually a response from an enterprise to existing and/or potential constraints to implementing a growth strategy. These restrictions may be short-term and longterm, internal and external. Sometimes it is only a temporary strategy that is implemented to consolidate the existing system and create conditions for further expansion, sometimes it is a choice of management resulting from satisfaction with the existing market position of the business and financial results, or the result of unwillingness and inability to look for growth sources outside the comfort zones.

A financial strategy that is consistent with incremental growth strategy is significantly different from a financial strategy that is consistent with the requirements of intensive growth and diversification strategies. This applies to all elements of the financial strategy: financing structure, level of liquidity required and allocation policy (see Table 1).

When it comes to capital structure, the implementation of incremental growth strategies generally leads to greater levels of financial leverage. In the absence of significant investment requirements, a stable and predictable cash flow (low business risk) makes it possible to attract debt on favorable terms. Increasing financial leverage in such circumstances leads to a decrease in the cost of capital and an increase in the value of the company (a characteristic of the life cycle stage of maturity). The manager's focus shifts from growing in size (expanding the boundaries of the empire) to growing the efficiency of the business. From the perspective of the value drivers, this implies a shift in focus from investment to cash flow and the cost of capital (case of company $\mathrm{Y}$ in Figure...). The primary task of managers is to increase business efficiency and grow returns on this basis. The return on equity can also be increased by minimizing the invested capital for a given level of business activity.

The value of a company that implements an incremental growth strategy, in the long run, is primarily based on the projection of existing cash flows. In such a context and for a given level of cash flow, minimizing the cost of capital by increasing financial leverage increases the value of the enterprise. Also, stable and positive cash flow in the absence of attractive investment options allows regular payment of high dividends and/or redemption of treasury shares. 
In the case of temporary stabilization strategies (pause strategy, harvest strategy, etc.), the financial strategy has a quite different purpose. The goal of the financial strategy is not to maximize value by minimizing the cost of capital, but to ensure the consolidation of the financial structure. After a long period of intensive growth and/or diversification of the company, it is necessary to temporarily stop and delay the realization of the investment plans. The pause strategy is aimed at consolidating the company in business, organizational and financial terms. Strengthening the financial structure is an indispensable part of this strategy, as intensive growth usually involves significant financing from borrowed sources. The implementation of the pause strategy leads to a reduction in the level of financial leverage (debt repayment, refinancing, etc.) in order to reduce the burden of business cash flow, increase financial flexibility and provide the capacity for financing further growth (implementation of the growth strategy). Essentially, the capital structure is put in place to support the future strategy. On the one hand, the existing capital structure is a consequence of the implementation of the past/current strategy, and on the other hand it also significantly influences the choice of the future strategy.

\section{Retrenchment strategies and capital structure}

The retrenchment strategies are featured by a significant reduction in the level of activities (downsizing) and/or narrowing of its scope (down-scoping). The implementation of these strategies is, as a rule, linked to the crisis context, which is manifested by a significant decline in enterprise performance. The retrenchment strategies represent management's response to the crisis the business is in. The implementation of these strategies is linked to the crisis context, which is manifested by a significant decline in the company's performance. Retrenchment represents the management's response to the crisis that the company is facing. The choice of a specific strategy depends on the cause of the crisis, the stage of the crisis and the potential for recovery. Retrenchment strategies include turnaround strategies, disinvestment, voluntary liquidation, and bankruptcy.

The retrenchment strategies are probably the most complex type of general strategies since they involve the implementation of multiple radical changes, which is why they are also called change strategies. These strategies are based on the simultaneous application of various strategic options such as recapitalization, disinvestment, relocation of activities, repositioning, consolidation, etc. The goal of retrenchment strategies is to revitalize the business, sell it or liquidate it.

The initial step in the process of making any planning decision is the analysis of the current position (diagnose) of the company. Choosing the right retrenchment strategy depends on what are the key causes of a decline in performance. This could be a fall in the level of economic 


\section{MANAGEMENT, BUSINESS \& FINANCE}

activity, an inadequate strategy, an inadequate implementation of an adequate strategy, shortage of key resources, the inefficiency of operations, over-investment, over-indebtedness, etc. In addition to the causes of the crisis, it is also necessary to diagnose the stage of the crisis. There are three stages of a crisis: operational, tactical crisis and strategic crisis.

The retrenchment strategies are used in the stage of the tactical and strategic crisis. The turnaround strategy is a response to the tactical crisis brought about by the implementation of the existing strategy. There are two options of this strategy: operational and strategic turnaround (Hofer, 1980). An operational turnaround implies the implementation of an existing strategy but with a set of operational measures whose effects are manifested in the short term (cost reduction, increase in revenue, assets disinvestment or a combination thereof). A strategic turnaround involves changing an existing strategy whose effects are long-termed and timedelayed. If the core business or a large number of businesses are located in branches with low growth rates, marginal and declining profitability, a shift towards more attractive businesses are required (entry into a new business). However, if key businesses lose their competitive position in attractive industries than a reversal of generic strategies applies.

The operational turnaround is usually applied when a crisis is triggered by internal factors, while a strategic turnaround is a response to a crisis caused primarily by external factors, as well as by a combination of internal and external factors.

According to Robbins and Pearce (1992), turning is a complex process composed of two phases: 1) the reduction phase and 2) the recovery phase (so-called "two-stage turnaround model"). In the first phase of the turnaround, strategic options for reducing costs and assets are applied to stop the trend of declining performance and stabilize the position of the company. The goal of the downsizing phase is to ensure viable and positive cash flow. In the second phase of the turnaround, recovery measures are in place to ensure profitable and sustainable growth. It is about choosing and implementing the right strategic growth option.

When looking at the turnaround strategy in this way, it is clear that its impact on the capital structure will depend on the measures taken at both the reduction and recovery stages. In particular, the first phase of the turnaround focuses on financial consolidation and strengthening the financing structure. The proceeds from the sale of assets are used to repay accumulated debts from the previous period. A sound capital structure is a fundamental prerequisite for implementing growth strategies in the recovery phase. As growth strategies are most commonly used in the recovery phase, their impact on the capital structure has already been discussed in the previous points. If the turnaround strategy does not produce the expected results, other retrenchment strategies such as divestment or liquidation should be implemented. 
A disinvestment is a strategic option that is very often used in managing large and diversified companies. It is about selling and eliminating businesses (divisions, product lines, etc.) from the company's portfolio. There are different options for disinvestment: sell-off, separate business as a spin-off, split-off, dissolution, etc. (Dess et al., 2014, p. 197). The main reasons for applying this strategy are: focusing on businesses that make up the business core, eliminating the energy, securing funding to finance the acquisition of attractive businesses, strengthening the financial structure (paying off debts), avoiding hostile takeovers, etc.

Successful businesses are most often characterized by an active process of disinvestment and investment (acquisition). Companies such as Siemens, Philips, Unilever, British Petroleum disinvested on average more than 10 businesses between 1990 and 2011, and acquired 8 new businesses (Kengelbach, Klemmer, \& Ross, 2012). Although it belongs to retrenchment strategies, disinvestment is a strategic option that can be implemented in conjunction with growth and stabilization strategies. Practically, the net effect of investing and disinvesting is to grow, stabilize or withdraw a business. Disinvestment provides funds for strengthening the financial structure and financing growth.

Failure to implement the previous strategies leads to the liquidation of the company. The voluntary liquidation strategy is the process of discontinuing an enterprise by the decision of the owner. If the value of the assets is not sufficient to cover the total liabilities, bankruptcy is initiated.

\section{Conclusion}

The general strategy determines the nature and scope of business activities of the firm, the economic and human organization that will emerge in the process and the interactions that the firm will have with stakeholders (Lowe et al., 1994, p. 246). A measure of the quality of a strategy is the value created for the owners. Whether a particular strategy will lead to value creation depends on its compatibility with the strategic context and the ability of managers to implement it appropriately. To what extent managers will be able to successfully implement a particular strategy certainly depends on the capital structure.

There are several reasons why the capital structure should be tailored to meet the specific requirements of the strategy. 
First, capital structure is a determinant of financial risk. Having in mind that the implementation of each strategy entails specific business risks, an unbalanced relationship between business and financial risk may result in bankruptcy. Second, capital structure is the determinant of the cost of capital, and therefore one of the most important drivers of the value of an enterprise. Third, capital structure is used as an instrument of corporate governance to minimize the negative effects caused by a conflict of interest in the principal-agent relationship. The use of debt certainly provides the proper discipline in managing cash flows. Forth, the current capital structure is a consequence of the implementation of the past/current strategy, but it significantly limits the choice of the future strategy.

The paper shows that different general strategies imply the application of different capital structures. When it comes to growth strategies, the related diversification strategy leads to the predominant equity financing, while in cases of unrelated diversification debt represents a preferred source of financing. A financial strategy that is consistent with stabilization and retrenchment strategies is significantly different from a financial strategy that is consistent with the requirements of intensive growth and diversification strategies. This applies to all elements of the financial strategy: financing structure, level of liquidity required and allocation policy. Based on all the above, it is obvious that understanding the relationship between strategy and capital structure is a prerequisite for achieving and maintaining competitiveness, especially in a rapidly changing context.

\section{References}

[1] Ansoff, I. (1957). Strategies for Diversification. Harvard Business Review, 35, Issue 5, 113 124.

[2] Barton, S. L., \& Gordon, P. I. (1987). Corporate strategy: Useful perspective for the study of capital structure. Academy of Management Review, 12(1), 67-75.

[3] Barton, S. L., \& Gordon, P. J. (1988). Corporate strategy and capital structure. Strategic Management Journal, 9(6), 623-632.

[4] Bettis, R. A. (1983). Modern financial theory, corporate strategy and public policy: Three conundrums. Academy of Management Review, 8(3), 406-415.

[5] Black, A., Wright, P., \& Bachman, J. In Search of Shareholder Value, 1998. Financial Times/Pitman Publishing, London. 


\section{MANAGEMENT, BUSINESS \& FINANCE}

[6] Brito J. A., \& John K. (2002). Leverage and growth opportunities: risk avoidance induced by risky debt. Working paper. University of New York: Salomon Centre. Stern School of Business.

[7] Bromiley, P. (1990). On the use of finance theory in strategic management. Advances in Strategic Management, 6, 71-98.

[8] Chatterjee, S., \& Wernerfelt, B. (1991). The link between resources and type of diversification: Theory and evidence. Strategic Management Journal, 12(1), 33-48.

[9] Dess, G., Lumpkin, G. T., Eisner, A., \& McNamara, G. (2014). Strategic Management Creating Competitive Advantages. Seventh global edition. New York: McGraw-Hill Education.

[10] Đuričin, D., Kaličanin, Đ., Lončar, D., \& Vuksanović Herceg, I. (2018). Menadžment i strategija. Dvanaesto izdanje. Beograd: Centar za izdavačku delatnost Ekonomskog fakulteta Univerziteta u Beogradu.

[11] Hofer, C. W. (1980). Turnaround strategies. Journal of Business Strategy, 1(1), 19-31.

[12] Hoffmann, W. H. (2007). Strategies for managing a portfolio of alliances. Strategic management journal, 28(8), 827-856.

[13] Jensen, M. C. (1986). Agency costs of free cash flow, corporate finance, and takeovers. AEA Papers and Proceedings, May.

[14] Johnson, G., Whittington, R. \& Scholes, K. (2011). Exploring Strategy: Text and Case Studies. $9^{\text {th }}$ edition. Financial Times Prentice Hall.

[15] Jordan, J., Lowe, J., \& Taylor, P. (1998). Strategy and financial policy in UK small firms. Journal of Business Finance and Accounting, 25, 1-27.

[16] Kaličanin. Đ., \& Todorović. M. (2014). Interactions between business and financial strategies in Serbian companies. Economic Annals, Vol. LIX, 203, Oct-Dec., 55-74.

[17] Kengelbach, J., Klemmer, D., \& Roos, A. (2012). How M\&A Can Grow Portfolio Value. Plant and Prune. The 2012 M\&A Report. BCG. Available at: https://www.bcgperspectives.com/content/articles/mergers_acquisitions_divestitures_plan t_and_prune_m_and_a_2012/.

[18] Kochhar, R. \& Hitt, M. (1998). Linking corporate strategy to capital structure: diversification strategy, type and source of financing. Strategic Management Journal, Vol. 19, 601-610.

[19] Kochhar, R. (1996). Explaining firm capital structure: the role of agency theory vs transaction cost economics", Strategic Management Journal, Vol. 17, 713-728. 


\section{MANAGEMENT, BUSINESS \& FINANCE}

[20] Koller, T., Goedhart, M., \& Wessels, D. (2015). Valuation: Measuring and Managing Value of Companies. Sixth edition. McKinsey \& Company. New York: John Wiley \& Sons, Inc.

[21] Kuč, V. (2015). Uloga i značaj strukture kapitala u stvaranju vrednost. In: Kaličanin, Đ., Lončar, D., Bogetić, Z., Todorović, M. (Editors). Stvaranje vrednosti: Teorijsko praktični aspekti (pp. 115-132). Faculty of Economics University of Belgrade.

[22] Kuč, V., \& Kaličanin, Đ. (2018). Various aspects of interdependence between corporate strategy and capital structure. Multidisciplinary Academic Conference on Management, Marketing and Economics (MAC-MME 2018), Academic Conferences Association, z.s., Prague, Czech Republic, 7 - 9. decembar, pp. 40-47.

[23] La Rocca, M., La Rocca, T, Gerace, D., \& Smark, C. (2009). Effect of Diversification on Capital Structure. Accounting \& Finance, Vol. 49 (4), 799-826.

[24] Lemmon, M. L., \& Zender, J. F. (2019). Asymmetric information, debt capacity, and capital structure. Journal of Financial and Quantitative Analysis, 54(1), 31-59.

[25] Li, D., \& Li, S. (1996). A theory of corporate scope and financial structure. The Journal of Finance, 51(2), 691-709.

[26] Lowe, J., Naughton, T., \& Taylor, P. (1994). The impact of corporate strategy on the capital structure of Australian companies. Managerial and Decision Economics, 15(3), 245257.

[27] Lubatkin, M., Chatterjee, S., 1994. Extending modern portfolio theory into the domain of corporate diversification: does it apply? Academy of Management Journal 37, 109-136.

[28] Modigliani, F. \& Miller, M. (1958). The cost of capital, corporate finance and theory of investment. American Economic Review, Vol. 48, 261-297.

[29] Moyer, C., McGuigan J., Rao, R., \& Kretlow, W. (2012). Contemporary Financial Management. South-Western Cengage Learning.

[30] Myers, S. C., \& Majluf, N. S. (1984). Corporate financing and investment decisions when firms have information that investors do not have. Journal of financial economics, 13(2), 187-221.

[31] Pettit, J. (2007). Strategic corporate finance: Application in valuation and capital structure. New York: John Wiley \& Sons, Inc.

[32] Robbins, K. D., \& Pearce, J. A. (1992). Turnaround: Retrenchment and recovery. Strategic Management Journal, 4, 287-309.

[33] Rumelt, R. P. (1974). Strategy, structure, and economic performance. Division of Research. Harvard Business School. 


\section{MANAGEMENT, BUSINESS \& FINANCE

[34] Rumelt, R. P. (1982). Diversification strategy and profitability. Strategic management journal, 3(4), 359-369.

[35] Simerly, R., \& Li, M. (2000). Environmental dynamism, capital structure and performance: a theoretical integration and an empirical test. Strategic Management Journal, Vol. 21, No. 1, 31-49.

[36] Taylor, P., \& Lowe, J. (1995). A note on corporate strategy and capital structure. Strategic Management Journal, 16(5), 411-414.

[37] Villarón-Peramato, Ó., Martínez-Ferrero, J., \& García-Sánchez, I. M. (2018). CSR as entrenchment strategy and capital structure: corporate governance and investor protection as complementary and substitutive factors. Review of Managerial Science, 12(1), 27-64.

[38] Williamson, O. (1988). Corporate finance and corporate governance. Journal of Finance, 43 (3), 567-591. 